\title{
IDENTIFIKASI HALITOSIS BERDASARKAN TINGKATAN BERBASIS SENSOR GAS MENGGUNAKAN METODE LEARNING VECTOR QUANTIZATION
}

\author{
Anisa Irviana ${ }^{1}$, Andrizal ${ }^{2}$, Dodon Yendri ${ }^{3}$ \\ ${ }^{1}$ Sistem Komputer Fakultas Teknologi Informasi Universitas Andalas \\ ${ }^{2}$ Teknik Elektronika Politeknik Negeri Padang \\ ${ }^{3}$ Sistem Komputer Fakultas Teknologi Informasi Universitas Andalas \\ anisairviana@yahoo.com 1), andrizalpoli@gmail.com²),dodon@fti.unand.ac.id ${ }^{3)}$
}

\begin{abstract}
ABSTRAK
Penyakit diabetes mellitus dan infeksi lambung dapat dideteksi melalui bau mulut tidak sedap penderita (halitosis). Halitosis merupakan suatu keadaan di mana terciumnya bau mulut pada saat seseorang mengeluarkan nafas (biasanya tercium pada saat berbicara). Penelitian ini bertujuan untuk membuat suatu sistem identifikasi dan klasifikasi kesehatan mulut (halitosis). Sensor gas TGS-2602 akan mendeteksi kadar gas pada mulut penderita, dan mengirim data berupa sinyal analog ke mikrokontroler ATmega 328. Dengan melakukan pemrograman baca data pada Raspberry Pi, data dari mikrokontroler disimpan pada sebuah file dan kemudian data tersebut diolah menggunakan metode Fast Fourier Transform (FFT) sehingga didapatkan pola data yang diinginkan. Pola data hasil keluaran Fast Fourier Transform (FFT) ini akan digunakan sebagai data input pada metode jaringan saraf tiruan Learning Vector Quantization (LVQ). Pengujian sistem dilakukan kepada orang dengan bau mulut penderita halitosis dan tidak halitosis. Hasil penelitian diperoleh persentase tingkat keberhasilan respon sensor terhadap sampel halitosis ringan 25\%, sampel halitosis sedang 50\%, sampel Halitosis akut $50 \%$ dan sampel tidak halitosis $100 \%$.
\end{abstract}

Kata Kunci: Sensor Gas TGS-2602, Halitosis, FFT, LVQ, Raspberry Pi

\begin{abstract}
Diabetes mellitus and gastrointestinal infections can be detected through an unpleasant mouth odor patients (halitosis). Halitosis is a condition in which the strong smell of someone's mouth during exhale (usually smell during the speech). This research aims to create a system of identification and classification of oral health (halitosis). TGS-2602 gas sensor will detect levels of gas at the mouth of the patient, and send data in the form of an analog signal to a microcontroller ATmega 328. By doing programming read data on Raspberry Pi, data from the microcontroller is stored in a file and then the data is processed using Fast Fourier Transform (FFT) to obtain the desired data pattern. The pattern of the data output Fast Fourier Transform (FFT) will be used as input data to the neural network method Learning Vector Quantization (LVQ). System testing is done to people with bad breath halitosis and halitosis sufferers. The results were obtained percentage success rate sensor response on a sample of $25 \%$ mild halitosis, halitosis samples were $50 \%, 50 \%$ acute Halitosis samples and samples of halitosis is not $100 \%$.
\end{abstract}

Keywords : Gas sensor TGS-2602, Halitosis, FFT, LVQ, Raspberry Pi

\section{PENDAHULUAN}

Masalah kesehatan mulut merupakan faktor yang sangat mempengaruhi kepercayaan diri seseorang yang kita kenal sebagai halitosis. Halitosis merupakan suatu istilah yang digunakan untuk menerangkan adanya bau yang tidak sedap sewaktu terhembusnya udara yang disebabkan sisa makanan yang tertinggal dalam rongga mulut.
Seseorang dapat dikategorikan mengalami halitosis bila memiliki kadar $\mathrm{H} 2 \mathrm{~S}>1.5 \mathrm{ng} / 10 \mathrm{ml}, \mathrm{CH} 3 \mathrm{SH}>$ $0.5 \mathrm{ng} / 10 \mathrm{ml}$ dan $(\mathrm{CH} 3) 2 \mathrm{~S}>0,2 \mathrm{ng} / 10 \mathrm{ml}[1]$. Halitosis disebabkan oleh faktor intraoral dan ektraoral. Halitosis juga merupakan penyebab atau indikasi dari penyakit seperti diabetes mellitus dan infeksi lambung. Cara lain dalam mendeteksi halitosis ini yaitu dengan halimeter, yaitu alat yang digunakan dalam praktek dokter gigi. 
Berdasarkan uraian diatas, penulis telah membuat sebuah sistem otomatis untuk mengukur kadar dari taraf Volatile Sulfure Compounds (VSCs) dengan menggunakan sensor gas untuk menentukan tingkatan dari halitosis. Penentuan tingkatan halitosis ini memanfaatkan sensor gas yang dapat merespon unsur yang dominan pada bau mulut yaitu hydrogen sulfida. Hasil deteksi sensor gas diproses melalui metode Fast Fourier Transform (FFT) untuk merepresentasikan sinyal dalam domain perioda/waktu dan dalam domain frekuensi. Perioda dibutuhkan untuk sebuah isyarat atau gelombang untuk mencapai gelombang penuh dan dapat menentukan hasil periodesitasnya, sedangkan frekuensi untuk menentukan jumlah gelombang yang terjadi dalam 1 detik.

Selanjutnya hasil FFT diolah untuk mendapatkan pola data yang akan di jadikan sebagai input untuk diproses ke dalam jaringan saraf tiruan metode LVQ.

\section{TINJAUAN PUSTAKA}

\section{Pengertian Halitosisi}

Halitosis adalah bau tidak sedap yang keluar dari rongga mulut. Halitosis juga disebut dengan istilah oral malador, fetor ex ore atau fetor oris. Halitosis merupakan masalah rongga mulut yang sering ditemukan pada rongga mulut setelah insidensi karies dan kerusakan jaringan periodontal. Halitosis disebabkan karena adanya pembentukan VSCs yang terdiri dari $\mathrm{H} 2 \mathrm{~S}, \mathrm{CH} 3 \mathrm{SH}$ dan $(\mathrm{CH} 3) 2 \mathrm{~S}$.

\section{Penyebab Halitosis}

Halitosis atau bau mulut secara medis dibagi atas 2 macam yakni halitosis yang berasal dari dalam mulut (intraoral) dan halitosis yang berasal dari luar rongga mulut (ekstraoral). Halitosis intraoral disebabkan oleh karena kurangnya perhatian untuk menjaga kebersihan gigi dan mulut secara teratur. Sedangkan halitosis eksraoral disebabkan oleh penyakit saluran pencernaan, diabetes mellitus, penyakit hati dan saluran pernafasan. Penyebab halitosis intraoral mempunyai persentase lebih banyak dibandingkan dengan ekstraoral, yaitu sebesar $80-90 \%$. Selain itu halitosis ekstraoral juga bisa disebabkan oleh penggunaan obat-obatan yang mempunyai efek samping membuat mulut kering seperti obat antidepresi, diabetes dan darah tinggi.

\section{Diagnosis Halitosis}

Diagnosis halitosis sangat perlu dilakukan untuk mengetahui etiologi dari timbulnya halitosis tersebut. Dengan mengetahui etiologi secara pasti maka rencana perawatan terhadap pasien halitosis dapat dilakukan secara optimal. Pemeriksaan secara sistemik maupun intraoral sangat diperlukan untuk mengetahui etiologi seseorang mengalami halitosis.
Metode untuk mendiagnosa halitosis terbagi dua yaitu metode langsung dan metode tidak langsung. Metode langsung dilakukan dengan cara menghirup secara langsung gas-gas yang berasal dari rongga mulut pasien yang mengandung sulfur penyebab timbulnya halitosis. Metode tidak langsung biasanya dilakukan di laboratorium untuk mengetahui jenis mikroorganisme yang berperan dalam menghasilkan Volatile Sulfure Compounds (VSCs) atau mengidentifikasi gas-gas yang menjadi hasil metabolisme dari suatu bakteri yang dapat menyebabkan halitosis.

\section{Sensor Gas}

Sensor TGS-2602 memiliki tingkat sensitivitas dan selektifitas yang baik pada kontaminasi udara terhadap kadar gas di luar ruang seperti ammonia dan $\mathrm{H} 2 \mathrm{~S}$, konsentrasi yang rendah dari alkohol.
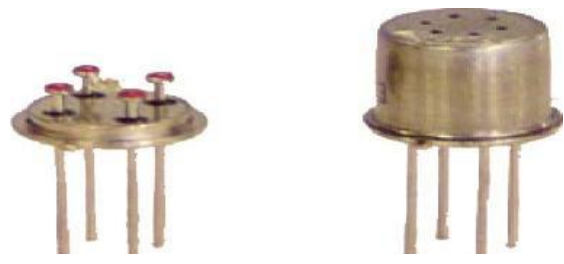

Gambar 1. Sensor Gas TGS-2602.

Gambar 1. Menunjukkan karakteristik sensitivitas sensor TGS-2602 untuk beberapa jenis gas. Pada sumbu y merupakan perbandingan resistansi sensor, dimana Rs merupakan resistansi sensor yang ditampilkan gas pada konsentrasi berbeda, dan Ro merupakan resistansi sensor pada udara bersih.

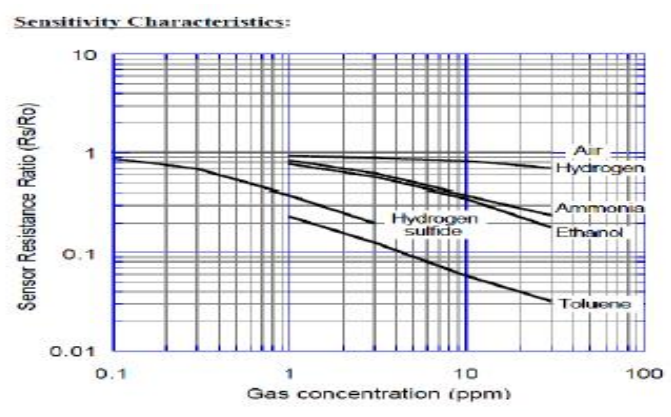

Gambar 2. Rasio hambatan sensor TGS-2602 dengan konsentrasi gas

\section{Fast Fourier Transform (FFT)}

FFT merupakan algoritma transformasi Fourier yang dikembangkan dari algoritma Discrete Transform Fourier (DFT). Dengan metode FFT, laju komputasi dari perhitungan transformasi Fourier dapat ditingkatkan. Transformasi Fourier berfungsi untuk merubah sebuah sinyal domain waktu untuk ditampilkan menjadi sinyal domain frekuensi. FFT banyak diterapkan dalam berbagai bidang, seperti pengolahan sinyal digital, memecahkan permasalahan differensial amplifier dan untuk mengalikan bilangan bulat besar. 
Metode Learning Vector Quantization (LVQ)

LVQ adalah suatu metode pembelajaran pada lapisan kompetitif yang terawasi. Suatu lapisan kompetitif digunakan untuk mengklasifikasikan vektor-vektor input. Kelas-kelas yang didapatkan sebagai hasil dari lapisan kompetitif akan tergantung pada jarak antara vektor-vektor input dengan vektor bobot. Apabila dua vektor input mendekati sama, maka lapisan kompetitif akan meletakkan kedua vektor input tersebut ke dalam kelas yang sama.

Hasil dari lapisan kompetitif ini berupa kelas, yang kemudian akan dihubungkan dengan lapisan output. Sebagai contoh ada delapan variabel dari vektor input, yaitu $\mathrm{X}=(\mathrm{X} 1, \mathrm{X} 2, \mathrm{X} 3, \mathrm{X} 4, \mathrm{X} 5, \mathrm{X} 6, \mathrm{X} 7, \mathrm{X} 8$, dengan unit keluaran Y1, Y2, Y3, Y4 serta empat vektor bobot, maka arsitektur jaringan LVQ dapat dirumuskan seperti gambar 3 berikut.

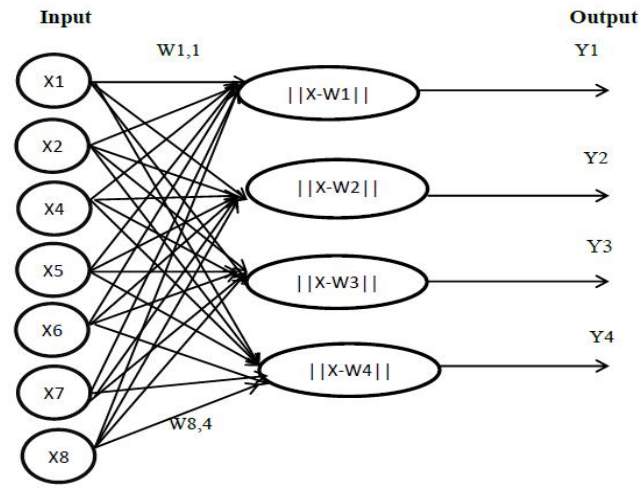

Gambar 3. Arsitektur jaringan learning vektor quantization dengan 8 input dan 4 vektor bobot

Berdasarkan Gambar 3 terlihat bahwa dalam LVQ terdapat dua vektor bobot yang menghubungkan setiap masukan dengan unit keluaran sehingga dapat dikatakan bahwa setiap keluaran pada LVQ berhubungan dengan sebuah vektor bobot. Pengenalan dalam metode LVQ ini terdapat dua proses, yaitu proses pembelajaran dan proses pengujian.

\section{Rasberry Pi}

Raspberry Pi merupakan single board seukuran kartu kredit. Dikarenakan ukurannya yang jauh lebih kecil dari komputer biasa, kemampuan komputer mini ini pun dibawah komputer biasa. Raspberry Pi kebanyakan digunakan untuk kegiatan pembelajaran yang tidak memerlukan alokasi memori yang besar seperti belajar pemrograman.

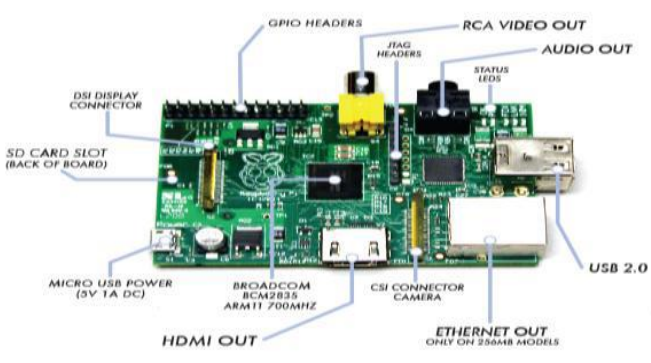

Gambar 4. Rasberry Pi

\section{METODE}

Metode penelitian yang digunakan dalam penelitian ini adalah Experimental Research yang dilakukan dalam beberapa tahapan yakni (1) studi literatur, (2) proses pembacaan sensor, (3) proses pengolahan sinyal dan (4) proses pengklasifikasian tingkatan seperti terlihat pada pada Gambar 5 berikut.

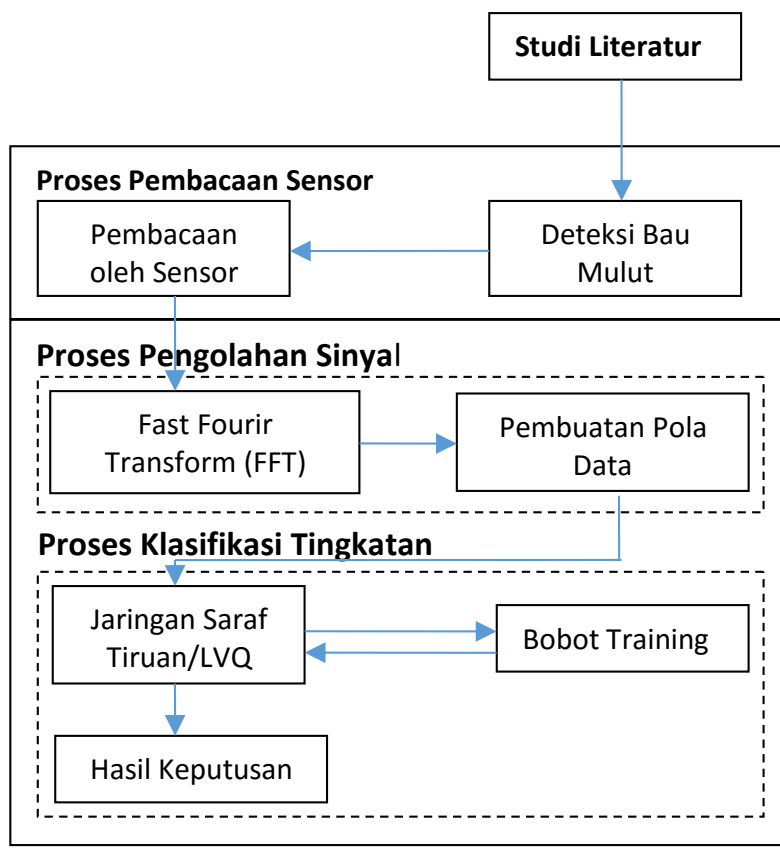

Gambar 5. Tahapan penelitian

\section{Perancangan}

Perancangan sistem diawali terlebih dahulu dengan membuat Blok Diagram Sistem seperti terlihat pada Gambar 6 dibawah ini.

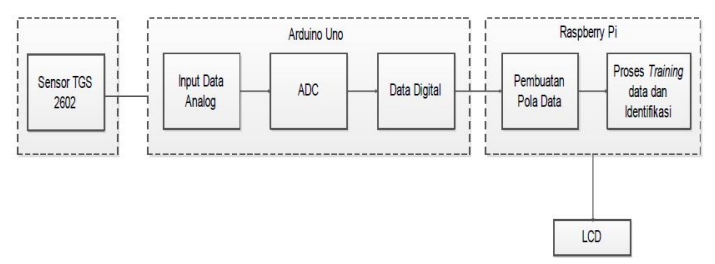

Gambar 6. Blok diagram sistem

Perancangan sistem terdiri dari perancangan perangkat keras dan perangkat lunak. Perangkat 
lunak meliputi program untuk pembacaan nilai tegangan hasil proses dari Mikrokontroller ATMega328 dan program untuk pengolahan data pada komputer untuk mendapatkan pola data gas H2S untuk diolah kembali menggunakan metode LVQ. Hasil pengolahan data menggunakan metode LVQ akan dihasilkan keputusan apakah responden tidak menderita halitosis, halitosis ringan, halitosis sedang dan halitosis akut.

Rangkaian Arduino Uno berbasiskan Mikrokontroller ATMega328 digunakan untuk pembacaan data sensor TGS 2602 dan dilakukan proses konversi data dari analog ke digital oleh modul ADC. Hasil konversi data berupa data data digital kemudian dikirimkan ke komputer melalui komunikasi serial serta pembangkit sinyal pemanas pulsa.

Pada Raspberry Pi dilakukan pemograman baca data dari mikrokontroller dan menyimpannya pada suatu file dan kemudian mengolahnya menggunakan metode Fast Fourier Transform (FFT) sehingga didapatkan pola data yang diinginkan. Selanjutnya pola data hasil keluaran Fast Fourier Transform (FFT) ini akan digunakan sebagai data input pada metode jaringan saraf tiruan Learning Vector Quantization (LVQ) sehingga didapatkan kelas keputusan yang akan ditampilkan pada LCD.

\section{HASIL DAN PEMBAHASAN}

\section{Mekanik Sistem}

Mekanik sistem ini terdiri dari wadah tempat sensor, Arduino Uno, kabel USB Kipas, Raspberry Pi dan LCD monitor seperti terlihat pada Gambar 7 berikut.

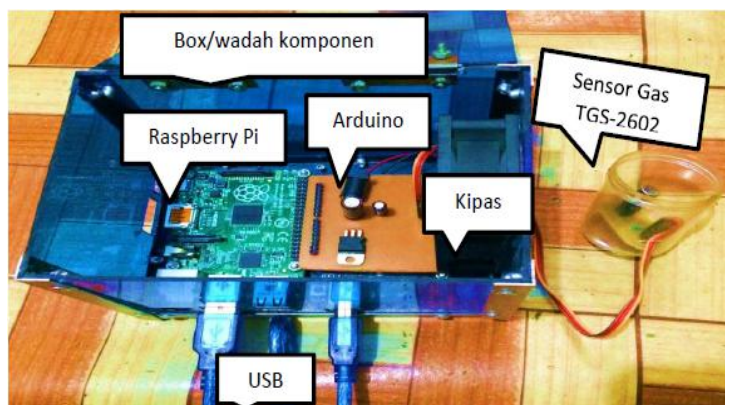

\section{Pengujian}

Pengujian Sensor TGS 2602

Sensor TGS-2602 memiliki nilai resistansi yang berubah-ubah apabila terkena gas. Keluaran dari sensor gas ini berupa tahanan, oleh karena itu di butuhkan rangkaian pengkondisian sinyal untuk mengubah keluaran tahanan dari sensor menjadi tegangan, tegangan input yang diberikan harus konstan dengan nilai tegangan masukan 5V DC.

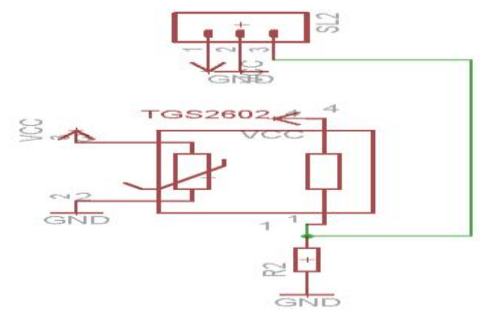

Gambar 8. Rangkaian pengkondisian sinyal

Pengujian rangkaian dilakukan dengan memberikan sampel nafas ke rangkaian sensor. Sensor TGS-2602 memiliki resistansi Rs yang akan berubah bila terkena bau. Untuk mencari nilai Rs, digunakan rumus berikut ini:

$$
R s=\frac{V_{c} x R_{l}}{V_{\text {out }}}-R_{l}
$$

Untuk mendapatkan tahanan dalam (Rs) dapat diuji berdasarkan hasil yang telah dibuat yaitu:

Untuk nilai $\mathrm{VRL}=0,525$ Volt, $\mathrm{Vc}=4,95$ Volt, dan $\mathrm{RL}=10 \mathrm{kOhm}$

$$
\begin{aligned}
& =\frac{0,95 \times 10 \mathrm{kOhm}}{0,525 \mathrm{~V}}-10 \mathrm{kOhm} \\
& =84,28 \mathrm{kOhm}
\end{aligned}
$$

Berikut merupakan beberapa hasil uji rangkaian sensor yang dilakukan sebanyak 6 kali:

Tabel 1. Data tahanan sensor

\begin{tabular}{llll}
\hline $\mathrm{V}_{\text {in }}$ & $\mathrm{V}_{\mathrm{RL}}(\mathrm{V})$ & $\mathrm{R}_{\mathrm{L}}(\mathrm{kOhm})$ & $\mathrm{R}_{\mathrm{S}}(\mathrm{kOhm})$ \\
\hline 4,95 & 0,525 & 10 & 84,28 \\
\hline 4,95 & 0,584 & 10 & 74,76 \\
\hline 4,95 & 0,592 & 10 & 73,61 \\
\hline 4,95 & 0,607 & 10 & 71,54 \\
\hline 4,95 & 0,618 & 10 & 70,09 \\
\hline 4,95 & 0,633 & 10 & 68,19 \\
\hline
\end{tabular}

Jadi, untuk nilai Rs berbanding terbalik dengan nilai $V_{R L}$. Semakin besar nilai $R_{s}$ maka semakin rendah nilai $\mathrm{V}_{\mathrm{RL}}$.

\section{Pengujian dan Analisa Rangkaian ADC}

Pengujian ADC dilakukan dengan memberikan tegangan input pada Arduino Uno kemudian ditampilkan pada multimeter untuk endapatkan data yang telah dikonversi. ADC yang digunakan adalah ADC 10 bit yang terdapat pada ATMega328, sehingga nilai $1 \mathrm{LSB}=5 \mathrm{~V} / 2^{10}=0,00488 \mathrm{~V}=4,88$ $\mathrm{mV}$.

Untuk mendapatkan nilai Out ADC berdasarkan hasil pengukuran $\mathrm{V}_{\text {out }}$ sensor dapat digunakan persamaan:

$$
\text { OutADC }=\frac{V_{\text {out }} \text { sensor }}{4,88 m V} \ldots \ldots
$$


Berikut adalah beberapa hasil uji rangkaian ADC yang dilakukan sebanyak 6 kali:

Tabel 2. Tabel pengukuran ADC

\begin{tabular}{lll}
\hline $\begin{array}{l}\mathrm{V}_{\text {out }} \\
\text { Sensor }\end{array}$ & $\begin{array}{l}\text { Out ADC } \\
\text { (serial } \\
\text { monitor) }\end{array}$ & $\begin{array}{l}\text { Out ADC } \\
\text { (perhitungan) }\end{array}$ \\
\hline 0,525 & 106 & 110 \\
\hline 0,584 & 109 & 122 \\
\hline 0,592 & 114 & 124 \\
\hline 0,607 & 119 & 127 \\
\hline 0,618 & 122 & 129 \\
\hline 0,633 & 123 & 132 \\
\hline
\end{tabular}

Pengujian Respon Sensor TGS-2602

Pengujian respon sistem dilakukan dengan menggunakan Raspberry Pi. Respon sensor memperlihatkan data uji sampel yang dilakukan dengan cara meniupkan nafas kedalam ruang/wadah yang berisi sensor gas, dimana sensor akan merespon langsung gas $\mathrm{H}_{2} \mathrm{~S}$ yang keluar dari dalam mulut. Setelah sensor merespon gas $\mathrm{H}_{2} \mathrm{~S}$, hasilnya dapat dilihat pada monitor yang mengulang (panjangnya 32 spektrum) dimana sebelumnya telah di set pada Arduino sebanyak 32 kali. Monitor dihubungkan dengan HDMI pada Raspberry Pi, kemudian data keluaran yang telah diproses di Raspberry Pi tersebut akan di training di Matlab dengan menggunakan laptop dan mendapatkan nilai bobot awal dan bobot akhir. Nilai bobot ini dijadikan sebagai input identifikasi pada Raspberry Pi yang akan menghasilkan keputusan apakah sampel yang diinputkan tidak halitosis, halitosis ringan, halitosis sedang dan halitosis akut.

\section{Respon Sensor Terhadap Data Tidak Halitosis}

Pengambilan data respon sensor terhadap sampel tidak halitosis dilakukan sampai counter ke-32. Tetapi untuk input hanya digunakan 8 input spektrum saja, karena 8 itu adalah pola unik yang telah didapat dari hasil output FFT, yakni dari counter $13,14,15,16,17,18,19,20$. Berikut data dan grafiknya dapat dilihat pada tabel 3 dan gambar 9 dengan 5 kali percobaan.

Tabel 3. Respon sensor terhadap data tidak halitosis

\begin{tabular}{|c|c|c|c|c|c|c|c|c|}
\hline \multirow[b]{2}{*}{ Percobaaan } & \multicolumn{8}{|c|}{ MAGNITUDE SPEKTRUM } \\
\hline & $(\mathrm{X} 13)$ & (X14) & $(\mathrm{X} 15)$ & $(\mathrm{X} 16)$ & (X17) & $(\mathrm{X} 18)$ & $(\mathrm{X} 19)$ & (X20) \\
\hline 1 & 0,304839 & 0,319355 & 0,314516 & 0,324194 & 0,309677 & 0,150000 & 0,295161 & 0,280645 \\
\hline 2 & 0,3 & 0,304839 & 0,285484 & 0,217742 & 0,227419 & 0,275806 & 0,290323 & 0,227419 \\
\hline 3 & 0,454839 & 0,450000 & 0,464516 & 0,450000 & 0,464516 & 0,464516 & 0,474194 & 0,440323 \\
\hline 4 & 0,280645 & 0,198387 & 0.304839 & 0.280645 & 0.270968 & 0.256452 & 0.26129 & 0,246774 \\
\hline 5 & 0,382258 & 0,377419 & 0,237097 & 0,358065 & 0,358065 & 0,348387 & 0,333871 & 0,300000 \\
\hline
\end{tabular}

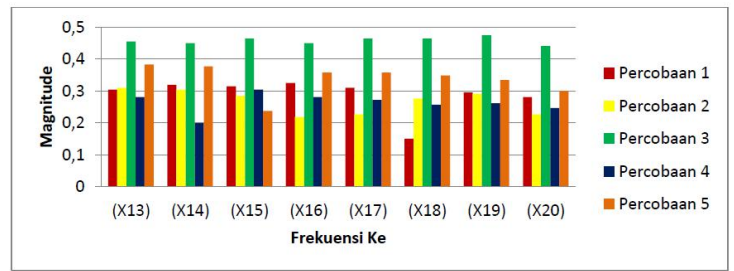

Gambar 9. Grafik respon sensor terhadap data tidak halitosis

Berdasarkan tabel 3 dan gambar 9 diperoleh hasil yang bermacam-macam, seperti terlihat pada table, dari percobaan 1 sampai 5 didapatkan magnitude spektrum yang beragam dan unik. Data magnitude spektrum tersebut merupakan keluaran dari sensor gas yang telah di konversi menjadi data digital. Sensor TGS-2602 dapat memberikan respon terhadap sampel tidak halitosis, namun respon sensor tidak terlalu besar. Pada grafik dengan magnitude 0 sampai 0,5 dapat pula dilihat bahwa pada percobaan yang ke-3 grafiknya lebih tinggi dari yang lainnya, yaitu hampir mencapai magnitude 0,5 . Pada percobaan ke-1 dan ke-2 nya mencapai nilai magnitude dari $0,2-0,3$ dan pada percobaan ke-4 dan ke-5 mencapai nilai magnitude dari $0,2-0,4$.

\section{Respon Sensor terhadap data Halitosis Ringan}

Pengambilan data respon sensor terhadap sampel data halitosis ringan sama dengan pegambilan data tidak halitosis.Hasil pengujian respon sensor terhadap data halitosis ringan dapat dilihat pada tabel 4 dan gambar 10 berikut.

Tabel 4. Respon sensor terhadap sampel halitosis ringan

\begin{tabular}{|c|c|c|c|c|c|c|c|c|}
\hline \multirow[b]{3}{*}{ Percobaan } & \\
\hline & \multicolumn{8}{|c|}{ MAGNITUDE SPEKTRUM } \\
\hline & (X13) & (X14) & (X15) & (X16) & (X17) & (X18) & (X19) & (X20) \\
\hline 1 & 1,079032 & 1,112903 & 1,122581 & 1,108065 & 1,117742 & 1,112903 & 1,117742 & 1,103226 \\
\hline 2 & 0,382258 & 0,41129 & 0,377419 & 0,425806 & 0,445161 & 0,459677 & 0,469355 & 0,464516 \\
\hline 3 & 0,440323 & 0,435484 & 0,517742 & 0,425806 & 0,425806 & 0,420968 & 0,425806 & 0,401613 \\
\hline 4 & 0,537097 & 0,537097 & 0,546774 & 0,575806 & 0,546774 & 0,633871 & 0,541935 & 0,527419 \\
\hline 5 & 0,48871 & 0,551613 & 0,483871 & 0,566129 & 0,546774 & 0,556452 & 0,56129 & 0,54193 \\
\hline
\end{tabular}

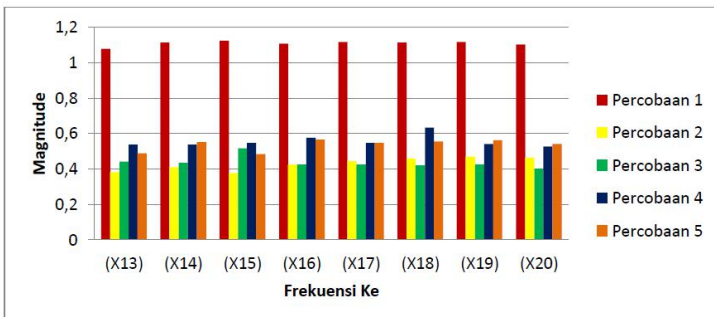

Gambar 10. Grafik respon sensor terhadap sampel halitosis ringan

Berdasarkan tabel 4 dan gambar 10 di atas dari 5 kali percobaan terhadap sampel halitosis ringan, dimana hasil dari magnitude spektrum data sampel halitosis ringan di dapatkan hasil yang beragam. Sensor juga mampu merespon data dari sampel halitosis ringan, dimana hasilnya lebih tinggi dari 
sampel tidak halitosis. Hal ini dapat dilihat dari nilai magnitude antara 0 sampai dengan 1,2. Pada percobaan ke-1 nilai magnitude-nya lebih tinggi dari percobaan lainnya yaitu mencapai 1,2. Pada percobaan ke-2 dan ke-3 mencapai nilai magnitude 0,4 dan percobaan ke-5 mencapai 0,6.

Respon Sensor terhadap data Halitosis Sedang Pengambilan data respon sensor terhadap sampel data halitosis sedang, juga sama dengan pengambilan data tidak halitosis dan halitosis ringan. Pengujian respon sensor data halitosis sedang ini juga dilakukan 5 kali percobaan, berikut tampilan hasil pengujian yang dapat dilihat pada tabel 6 dan gambar 11 berikut.

Tabel 6. Respon sensor terhadap sampel halitosis sedang
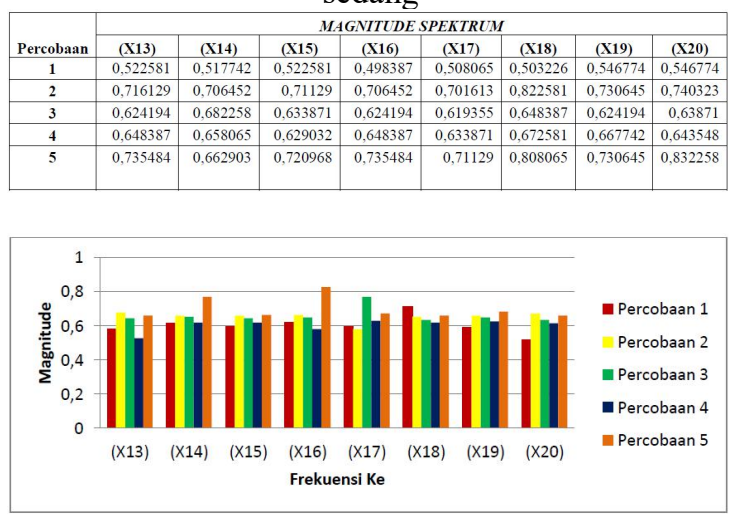

Gambar 11. Grafik respon sensor terhadap sampel halitosis sedang

Dari tabel 6 dan gambar 11, terlihat bahwa dari pengambilan data yang dilakukan selama 5 kali percobaan, didapatkan hasil yang berbeda. Hal ini dapat dilihat pada magnitude spektrum sampel halitosis sedang berupa data digital yang telah didapatkan dari hasil konversi sebelumnya. Grafik tertinggi terletak pada percobaan ke-5 pada counter ke-16.

\section{Respon Sensor terhadap data halitosis akut/berat}

Pada pengujian ini, pengambilan data respon sensor terhadap sampel data halitosis akut juga sama dengan pegambilan data sebelumnya. Adapun hasil uji respon data halitosis akut yang dilakukan 5 kali percobaan dapat dilihat pada tabel 7 dan gambar 12 .

Tabel 7. Respon sensor terhadap sampel halitosis akut

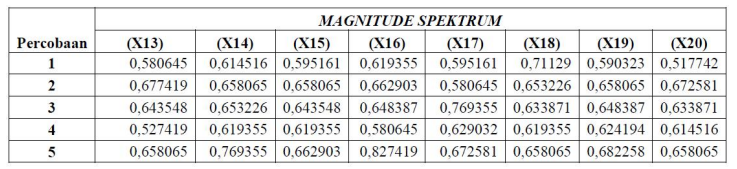

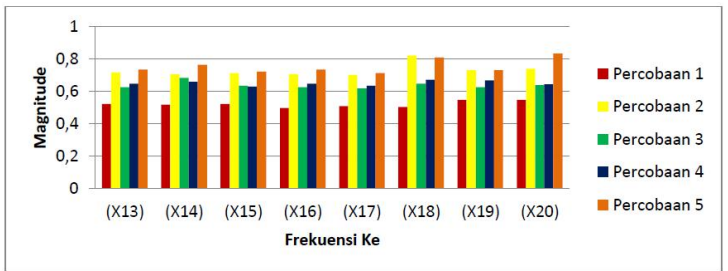

Gambar 12. Grafik respon sensor terhadap sampel halitosis akut

Dari hasil uji yang disajikan pada tabel 7 dan gambar 12, dari kelima percobaan diatas didapatkan hasil yang berbeda. Jarak magnitude yang di dapatkan dari 0 sampai 1 . Grafik respon sensor tertinggi terdapat pada percobaan ke-2 yang diikuti percobaan ke-5 pada counter ke-18 dan ke-20 yang nilai magnitude spektrumnya melewati angka 0,8 .

\section{Pengujian Sistem Keseluruhan}

Pengujian sistem secara keseluruhan dengan menggunakan metode LVQ. Input yang digunakan sebanyak 8 yang berasal dari keluaran FFT dan 4 output. Digunakan sebanyak 4 output karena kategori hasil yang diinginkan yaitu tidak halitosis, halitosis ringan, halitosis sedang dan halitosis akut.

\section{Uji Training Learning Vector Quantization}

Proses training yang dilakukan pada metode LVQ terhadap sampel tidak halitosis, halitosis ringan, halitosis sedang dan halitosis akut, dimana input data diambil dari nilai magnitude 32 counter dari hasil output FFT.

Delapan input untuk proses training, yaitu counter ke $13,14,15,16,17,18,19$, dan 20 yang merupakan pola unik yang telah didapat dari output FFT. Tabel 8 memperlihatkan data bobot awal training yang akan digunakan pada proses uji LVQ.

Tabel 8. Bobot awal training

\begin{tabular}{|c|c|c|c|c|c|c|c|c|c|}
\hline DATA & \multicolumn{8}{|c|}{ BOBOT AWAL TRAINING } & KEL \\
\hline & $\mathbf{x} 1(13)$ & $\mathrm{X} 2(14)$ & $\mathbf{X 3}(15)$ & $\mathrm{X} 4(16)$ & $\mathrm{x} 5(17)$ & $\mathrm{X} 6(18)$ & $\mathrm{x} 7(19)$ & $\mathrm{x} 8(20)$ & \\
\hline 1 & 0,309677 & \begin{tabular}{|l|}
0,304839 \\
\end{tabular} & 0,285484 & 0,217742 & \begin{tabular}{|l|}
0,227419 \\
\end{tabular} & 0,275806 & 0,290323 & 0,227419 & 1 \\
\hline 2 & 822 & 0,41129 & 0.377419 & 425806 & (4) & 0,459677 & 0.469355 & 0.46 & \\
\hline 3 & 0,716129 & 0,706452 & 0,71129 & 0,706452 & 0,701613 & 0,822581 & 0,730645 & 0,740323 & 3 \\
\hline 4 & 0,677419 & 0,658065 & 0,658065 & 0,662903 & 0,580645 & 0,653226 & 0,658065 & 0,672581 & 4 \\
\hline
\end{tabular}

Nilai bobot awal didapatkan dari hasil deviasi seluruh sampel dari 5 percobaan yang telah dilakukan sebelumnya. Pada proses training ini terlebih dahulu ditentukan nilai alpha sebesar 0,05 dengan penurunan tingkat pembelajaran sebesar 0,1*alpha dan maksimum epoch-nya sebesar 100 .

Proses training LVQ dilakukan menggunakan pemograman Matlab untuk mendapatkan nilai bobot. Pada proses training, target kelas ditentukan untuk dijadikan hasil identifikasi terhadap sampel yang akan diuji. Kelas ditentukan berdasarkan 4 inputan sampel yang diambil. Bobot hasil setelah training menggunakan Matlab dapat dilihat pada table 9 berikut. 
Tabel 9. Bobot akhir hasil training pada matlab

\begin{tabular}{|c|c|c|c|}
\hline $\mathbf{W}(\mathbf{1})$ & $\mathbf{W}(\mathbf{2})$ & $\mathbf{W}(\mathbf{3})$ & $\mathbf{W}(\mathbf{4})$ \\
\hline 0,3916 & $-0,1441$ & 0,4810 & 1,0910 \\
\hline 0,4300 & 0,0207 & 0,4020 & 0,6561 \\
\hline 0,2373 & $-0,2407$ & 0,3942 & 0,7930 \\
\hline 0,2016 & 0,1207 & 0,4295 & 0,6743 \\
\hline 0,2376 & 0,2540 & 0,2411 & $-0,0210$ \\
\hline 0,4503 & 0,2991 & 1,1379 & 0,4379 \\
\hline 0,3518 & 0,3604 & 0,5654 & 0,6742 \\
\hline 0,2404 & 0,4470 & 0,7217 & 0,7732 \\
\hline \multicolumn{4}{|l|}{} \\
\hline
\end{tabular}

Bobot akhir training ini akan menjadi bobot identifikasi yang selanjutnya akan digunakan sebagai identifikasi hasil keputusan semua sampel uji pola data FFT yang telah didapatkan, apakah tidak halitosis, halitosis ringan, halitosis sedang dan halitosis akut. Berikut adalah hasil uji Bobot Akhir Hasil Training LVQ dengan input hasil FFT yang dapat dilihat pada tabel 10 .

Tabel 10. Bobot akhir hasil training LVQ

\begin{tabular}{|c|c|c|c|c|c|c|c|c|}
\hline DATA & \multicolumn{7}{|c|}{ BOBOT AKHIR } \\
\hline 1 & 0,3916 & 0,43 & 0,2373 & 0,2016 & 0,2376 & 0,4503 & 0,3518 & 0,2404 \\
\hline 2 & $-0,1441$ & 0,0207 & $-0,2407$ & 0,1207 & 0,254 & 0,2991 & 0,3604 & 0,447 \\
\hline 3 & 0,481 & 0,402 & 0,3942 & 0,4295 & 0,2411 & 1,1379 & 0,5654 & 0,7217 \\
\hline 4 & 1,091 & 0,6561 & 0,793 & 0,6743 & $-0,0201$ & 0,4379 & 0,6742 & 0,7732 \\
\hline
\end{tabular}

\section{Uji Identifikasi}

Proses identifikasi yang dilakukan hampir sama dengan proses training, proses ini dilakukan untuk mencari selisih terkecil atau jarak minimum antara vektor input dengan bobot akhir hasil training. Kelas ditentukan berdasarkan data input sampel mana yang diambil. Karena terdapat 4 sampel maka kelas yang digunakan juga 4, dimana masing-masing kelas mewakili ouput dari hasil identifikasi. Kelas $1=$ tidak halitosis, kelas $2=$ halitosis ringan, kelas $3=$ halitosis sedang dan kelas $4=$ halitosis akut.

\section{Tidak Halitosis}

Uji identifikasi sampel tidak halitosis dilakukan dengan 4 kali percobaan masing-masing 8 buah input spektrum dan 4 buah output proses identifikasi yaitu Y1 (tidak halitosis), Y2 (halitosis ringan), Y3 (halitosis sedang) dan Y4 (halitosis akut). Hasil uji sampel tidak halitosis ini dihasilkan suatu keputusan bahwa sampel teridentifikasi tidak halitosis 100\%. Karena dari ke-4 pengujian didapatkan jarak terpendeknya terletak pada Y1 yang mewakili kelas (tidak halitosis) terdapat sebanyak 4 kali atau semuanya terpenuhi, yakni pengujian ke-1 didapatkan $\mathrm{Y} 1=0.9973$, pengujian ke-2 Y1= 1.0116, pengujian ke-3 Y1=0,9937 dan pengujian ke-4 Y1=0,9732. Berikut adalah hasil identifikasi sampel tidak halitosis yang disajikan pada tabel 11 berikut.
Tabel 11. Identifikasi sampel tidak halitosis

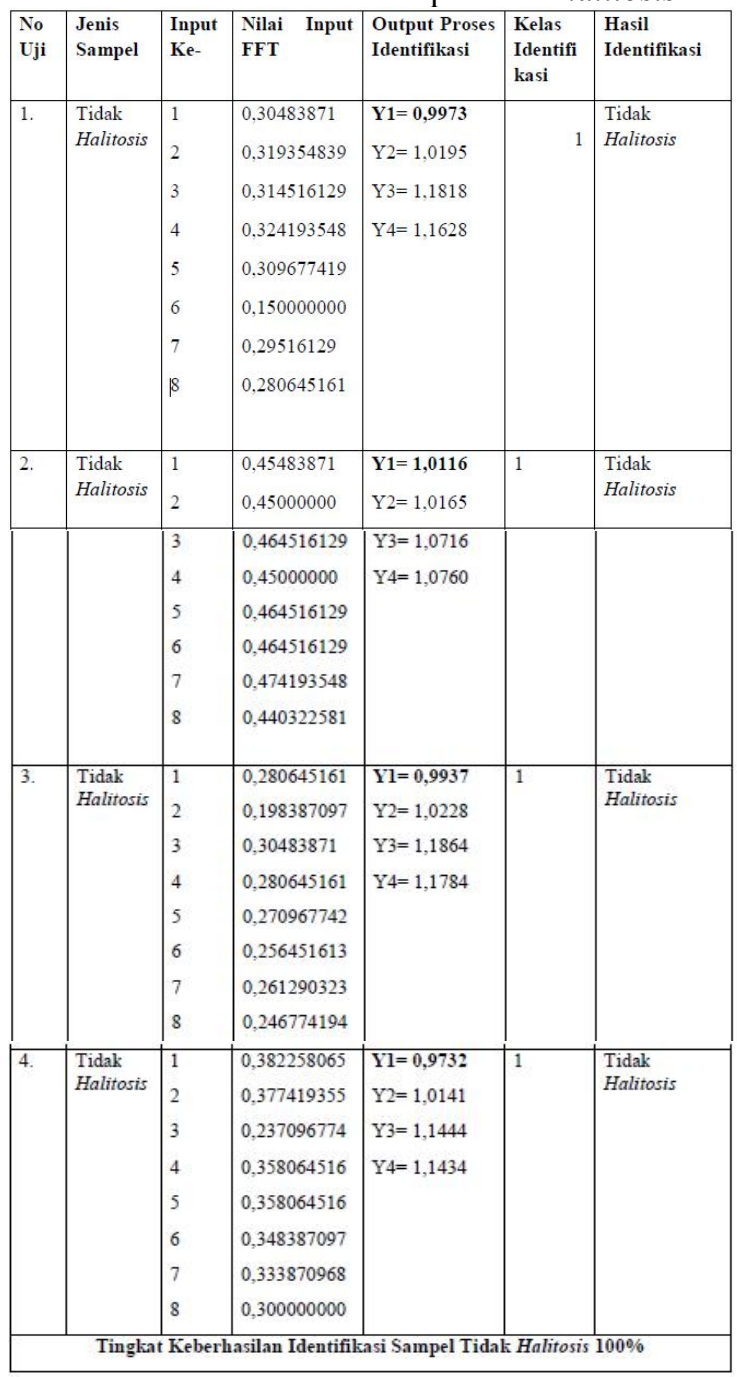

\section{Halitosis Ringan}

Uji identifikasi sampel halitosis dilakukan sama caranya dengan sampel tidak halitosis. Hasil uji menunjukkan bahwa tingkat keberhasilan identifikasi sampel halitosis ringan adalah sebesar $25 \%$. Hal ini dapat dilihat dari ouput hasil identifikasi dimana Y2-nya muncul dengan nilai terkecil satu kali Y2=1.0362 yang mewakili kelas halitosis ringan hanya teridentifikasi satu kali yaitu pada pengujian yang ke-4.

\section{Halitosis Sedang}

Hasil uji sampel halitosis sedang menunjukkan bahwa tingkat keberhasilan identifikasi sampel halitosis sedang adalah sebesar 50\%. Hal ini diperoleh karena terdapat dua kali nilai Y3-nya muncul dengan nilai paling kecil, yakni $\mathrm{Y} 3=1,0322$ pada pengujian ke-3 dan $\mathrm{Y} 3=1,0347$ pada pengujian ke-4.

\section{Halitosis Akut}

Uji identifikasi sampel halitosis akut dilakukan sama caranya dengan sampel halitosis ringan. Hasil 
uji menunjukkan bahwa tingkat keberhasilan identifikasi sampel halitosis akut adalah sebesar $50 \%$. Hal ini dapat dilihat dari ouput hasil identifikasi dimana Y4-nya muncul dua kali dengan nilai terkecil $\mathrm{Y} 4=1,0406$ pada pengujian ke-2 dan Y4=1,0329 pada pengujian ke-4 yang mewakili kelas halitosis akut.

\section{HASIL DAN PEMBAHASAN}

\section{Mekanik Sistem}

Mekanik sistem ini terdiri dari wadah tempat sensor, Arduino Uno, kabel USB Kipas, Raspberry Pi dan LCD monitor seperti terlihat pada Gambar 13 berikut.

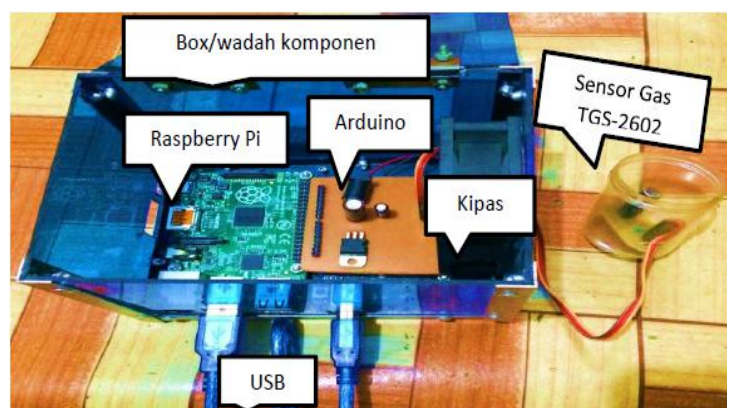

\section{Pengujian}

Pengujian Sensor TGS 2602

Sensor TGS-2602 memiliki nilai resistansi yang berubah-ubah apabila terkena gas. Keluaran dari sensor gas ini berupa tahanan, oleh karena itu di butuhkan rangkaian pengkondisian sinyal untuk mengubah keluaran tahanan dari sensor menjadi tegangan, tegangan input yang diberikan harus konstan dengan nilai tegangan masukan 5V DC.

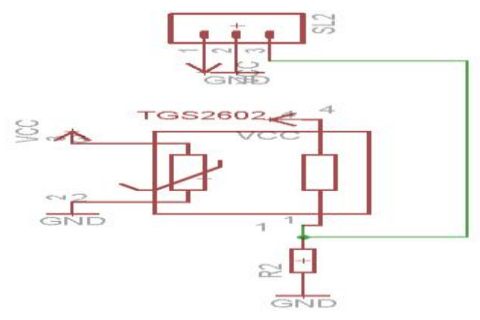

Gambar 14. Rangkaian pengkondisian sinyal

Pengujian rangkaian dilakukan dengan memberikan sampel nafas ke rangkaian sensor. Sensor TGS-2602 memiliki resistansi Rs yang akan berubah bila terkena bau. Untuk mencari nilai Rs, digunakan rumus berikut ini:

$$
R s=\frac{V_{c} x R_{l}}{V_{\text {out }}}-R_{l}
$$

Untuk mendapatkan tahanan dalam (Rs) dapat diuji berdasarkan hasil yang telah dibuat yaitu: Untuk nilai $\mathrm{VRL}=0,525$ Volt, $\mathrm{Vc}=4,95$ Volt, dan $\mathrm{RL}=10 \mathrm{kOhm}$

$$
\begin{aligned}
& =\frac{0,95 \times 10 \mathrm{kOhm}}{0,525 \mathrm{~V}}-10 \mathrm{kOhm} \\
& =84,28 \mathrm{kOhm}
\end{aligned}
$$

Berikut merupakan beberapa hasil uji rangkaian sensor yang dilakukan sebanyak 6 kali:

Tabel 12. Data tahanan sensor

\begin{tabular}{llll}
\hline $\mathrm{V}_{\text {in }}$ & $\mathrm{V}_{\mathrm{RL}}(\mathrm{V})$ & $\mathrm{R}_{\mathrm{L}}(\mathrm{kOhm})$ & $\mathrm{R}_{\mathrm{s}}(\mathrm{kOhm})$ \\
\hline 4,95 & 0,525 & 10 & 84,28 \\
\hline 4,95 & 0,584 & 10 & 74,76 \\
\hline 4,95 & 0,592 & 10 & 73,61 \\
\hline 4,95 & 0,607 & 10 & 71,54 \\
\hline 4,95 & 0,618 & 10 & 70,09 \\
\hline 4,95 & 0,633 & 10 & 68,19 \\
\hline
\end{tabular}

Jadi, untuk nilai Rs berbanding terbalik dengan nilai $V_{R L}$. Semakin besar nilai $R_{S}$ maka semakin rendah nilai $\mathrm{V}_{\mathrm{RL}}$.

\section{Pengujian dan Analisa Rangkaian ADC}

Pengujian ADC dilakukan dengan memberikan tegangan input pada Arduino Uno kemudian ditampilkan pada multimeter untuk endapatkan data yang telah dikonversi. ADC yang digunakan adalah ADC 10 bit yang terdapat pada ATMega328, sehingga nilai $1 \mathrm{LSB}=5 \mathrm{~V} / 2^{10}=0,00488 \mathrm{~V}=4,88$ $\mathrm{mV}$.

Untuk mendapatkan nilai Out ADC berdasarkan hasil pengukuran $\mathrm{V}_{\text {out }}$ sensor dapat digunakan persamaan:

$$
\text { OutADC }=\frac{V_{\text {out }} \text { sensor }}{4,88 m V}
$$

Berikut adalah beberapa hasil uji rangkaian ADC yang dilakukan sebanyak 6 kali:

Tabel 2. Tabel pengukuran ADC

\begin{tabular}{lll}
\hline $\begin{array}{l}\mathrm{V}_{\text {out }} \\
\text { Sensor }\end{array}$ & $\begin{array}{l}\text { Out ADC } \\
\text { (serial } \\
\text { monitor) }\end{array}$ & $\begin{array}{l}\text { Out ADC } \\
\text { (perhitungan) }\end{array}$ \\
\hline 0,525 & 106 & 110 \\
\hline 0,584 & 109 & 122 \\
\hline 0,592 & 114 & 124 \\
\hline 0,607 & 119 & 127 \\
\hline 0,618 & 122 & 129 \\
\hline 0,633 & 123 & 132 \\
\hline
\end{tabular}

\section{Pengujian Respon Sensor TGS-2602}

Pengujian respon sistem dilakukan dengan menggunakan Raspberry Pi. Respon sensor memperlihatkan data uji sampel yang dilakukan dengan cara meniupkan nafas kedalam ruang/wadah yang berisi sensor gas, dimana sensor akan merespon langsung gas $\mathrm{H}_{2} \mathrm{~S}$ yang keluar dari dalam mulut. Setelah sensor merespon gas $\mathrm{H}_{2} \mathrm{~S}$, hasilnya dapat dilihat pada monitor yang mengulang 
(panjangnya 32 spektrum) dimana sebelumnya telah di set pada Arduino sebanyak 32 kali. Monitor dihubungkan dengan HDMI pada Raspberry Pi, kemudian data keluaran yang telah diproses di Raspberry Pi tersebut akan di training di Matlab dengan menggunakan laptop dan mendapatkan nilai bobot awal dan bobot akhir. Nilai bobot ini dijadikan sebagai input identifikasi pada Raspberry Pi yang akan menghasilkan keputusan apakah sampel yang diinputkan tidak halitosis, halitosis ringan, halitosis sedang dan halitosis akut.

\section{Respon Sensor Terhadap Data Tidak Halitosis}

Pengambilan data respon sensor terhadap sampel tidak halitosis dilakukan sampai counter ke-32. Tetapi untuk input hanya digunakan 8 input spektrum saja, karena 8 itu adalah pola unik yang telah didapat dari hasil output FFT, yakni dari counter $13,14,15,16,17,18,19,20$. Berikut data dan grafiknya dapat dilihat pada tabel 3 dan gambar 9 dengan 5 kali percobaan.

Tabel 3. Respon sensor terhadap data tidak halitosis

\begin{tabular}{|c|c|c|c|c|c|c|c|c|}
\hline & \multicolumn{7}{|c|}{ MAGNITUE SPEKTRLM } \\
\cline { 2 - 9 } Percobaan & $(\mathrm{X} 13)$ & $(\mathrm{X} 14)$ & $(\mathrm{X} 15)$ & $(\mathrm{X} 16)$ & $(\mathrm{X} 17)$ & $(\mathrm{X} 18)$ & $(\mathrm{X} 19)$ & $(\mathrm{X} 20)$ \\
\hline 1 & 0,304839 & 0,319355 & 0,314516 & 0,324194 & 0,309677 & 0,150000 & 0,295161 & 0,280645 \\
\hline 2 & 0,309677 & 0,304839 & 0,285484 & 0,217742 & 0,227419 & 0,275806 & 0,290323 & 0,227419 \\
\hline 3 & 0,454839 & 0,450000 & 0,464516 & 0,450000 & 0,464516 & 0,464516 & 0,474194 & 0,40323 \\
\hline 4 & 0,280645 & 0,198387 & 0,304839 & 0,280645 & 0,270968 & 0,256452 & 0,26129 & 0,246774 \\
\hline $\mathbf{5}$ & 0,382258 & 0,377419 & 0,237097 & 0,358065 & 0,358065 & 0,348387 & 0,333871 & 0,300000 \\
\hline
\end{tabular}

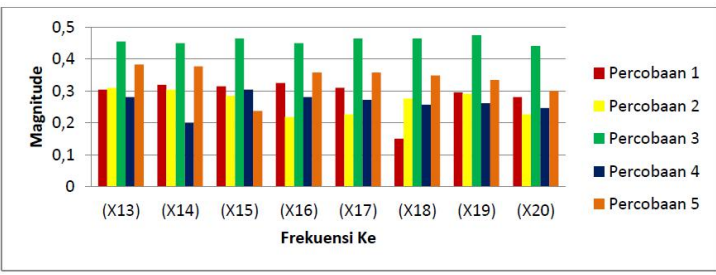

Gambar 9. Grafik respon sensor terhadap data tidak halitosis

Berdasarkan tabel 3 dan gambar 9 diperoleh hasil yang bermacam-macam, seperti terlihat pada table, dari percobaan 1 sampai 5 didapatkan magnitude spektrum yang beragam dan unik. Data magnitude spektrum tersebut merupakan keluaran dari sensor gas yang telah di konversi menjadi data digital. Sensor TGS-2602 dapat memberikan respon terhadap sampel tidak halitosis, namun respon sensor tidak terlalu besar. Pada grafik dengan magnitude 0 sampai 0,5 dapat pula dilihat bahwa pada percobaan yang ke-3 grafiknya lebih tinggi dari yang lainnya, yaitu hampir mencapai magnitude 0,5. Pada percobaan ke-1 dan ke-2 nya mencapai nilai magnitude dari 0,2-0,3 dan pada percobaan ke-4 dan ke-5 mencapai nilai magnitude dari $0,2-0,4$.

\section{Respon Sensor terhadap data Halitosis Ringan} Pengambilan data respon sensor terhadap sampel data halitosis ringan sama dengan pegambilan data tidak halitosis.Hasil pengujian respon sensor terhadap data halitosis ringan dapat dilihat pada tabel 4 dan gambar 10 berikut.

Tabel 4. Respon sensor terhadap sampel halitosis ringan

\begin{tabular}{|c|c|c|c|c|c|c|c|c|}
\hline \multirow[b]{3}{*}{ Percobaan } & \multicolumn{8}{|c|}{ ringan } \\
\hline & \multicolumn{8}{|c|}{ MAGNITUDE SPEKTRUM } \\
\hline & (X13) & (X14) & (X15) & (X16) & (X17) & (X18) & (X19) & $(\mathrm{X} 20)$ \\
\hline 1 & 1,079032 & 1,112903 & 1,122581 & 1,108065 & 1,117742 & 1,112903 & 1,117742 & 1,103226 \\
\hline 2 & 0,382258 & 41129 & 0,377419 & 0,425806 & 0,445161 & 0,459677 & 0,469355 & 0,464516 \\
\hline 3 & 0,440323 & 0,435484 & 0,517742 & 0,425806 & 0,425806 & 0,420968 & 0,425806 & 0,401613 \\
\hline 4 & 0,537097 & 0,537097 & 0,546774 & 0,575806 & 0,546774 & 0,633871 & 0,541935 & 0,527419 \\
\hline 5 & 0,48871 & 0,551613 & 0,483871 & 0,566129 & 0,546774 & 0,556452 & 0,56129 & 0,541935 \\
\hline
\end{tabular}

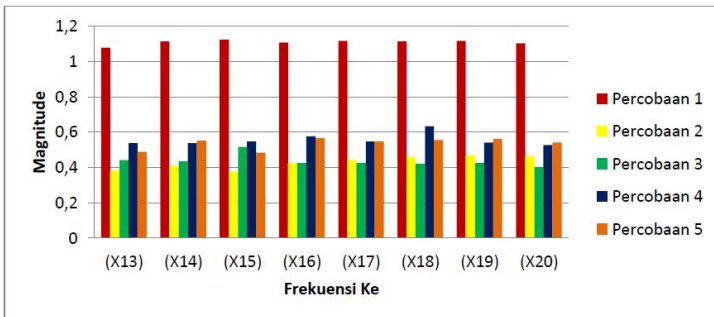

Gambar 10. Grafik respon sensor terhadap sampel halitosis ringan

Berdasarkan tabel 4 dan gambar 10 di atas dari 5 kali percobaan terhadap sampel halitosis ringan, dimana hasil dari magnitude spektrum data sampel halitosis ringan di dapatkan hasil yang beragam. Sensor juga mampu merespon data dari sampel halitosis ringan, dimana hasilnya lebih tinggi dari sampel tidak halitosis. Hal ini dapat dilihat dari nilai magnitude antara 0 sampai dengan 1,2. Pada percobaan ke-1 nilai magnitude-nya lebih tinggi dari percobaan lainnya yaitu mencapai 1,2. Pada percobaan ke-2 dan ke-3 mencapai nilai magnitude 0,4 dan percobaan ke-5 mencapai 0,6.

\section{Respon Sensor terhadap data Halitosis Sedang}

Pengambilan data respon sensor terhadap sampel data halitosis sedang, juga sama dengan pengambilan data tidak halitosis dan halitosis ringan. Pengujian respon sensor data halitosis sedang ini juga dilakukan 5 kali percobaan, berikut tampilan hasil pengujian yang dapat dilihat pada tabel 6 dan gambar 11 berikut.

Tabel 6. Respon sensor terhadap sampel halitosis sedang

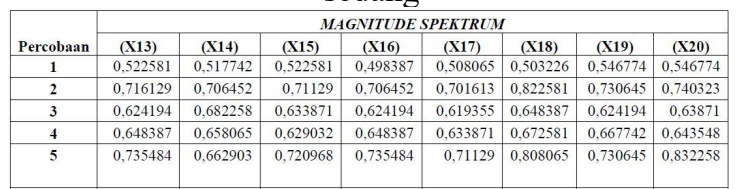




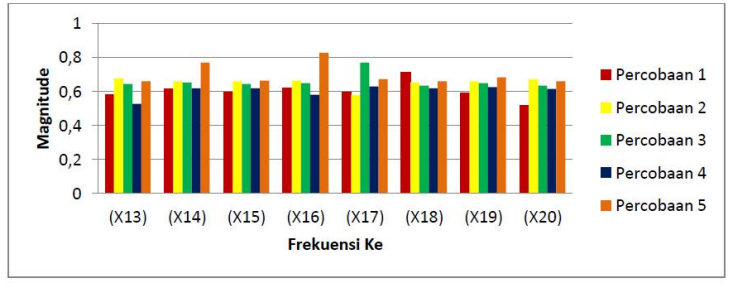

Gambar 11. Grafik respon sensor terhadap sampel halitosis sedang

Dari tabel 6 dan gambar 11, terlihat bahwa dari pengambilan data yang dilakukan selama 5 kali percobaan, didapatkan hasil yang berbeda. Hal ini dapat dilihat pada magnitude spektrum sampel halitosis sedang berupa data digital yang telah didapatkan dari hasil konversi sebelumnya. Grafik tertinggi terletak pada percobaan ke-5 pada counter ke-16.

\section{Respon Sensor terhadap data halitosis akut/berat}

Pada pengujian ini, pengambilan data respon sensor terhadap sampel data halitosis akut juga sama dengan pegambilan data sebelumnya. Adapun hasil uji respon data halitosis akut yang dilakukan 5 kali percobaan dapat dilihat pada tabel 7 dan gambar 12 .

Tabel 7. Respon sensor terhadap sampel halitosis akut

\begin{tabular}{|c|c|c|c|c|c|c|c|c|}
\hline \multirow[b]{2}{*}{ Percobaan } & \multicolumn{8}{|c|}{ MAGNITUDE SPEKTRUM } \\
\hline & (X13) & (X14) & (X15) & (X16) & $(\mathrm{X} 17)$ & (X18) & (X19) & (X20) \\
\hline 1 & 0.580645 & 0,614516 & 0.595161 & 0,619355 & 0.595161 & 0,71129 & 0.590323 & 0,517742 \\
\hline 2 & 0,677419 & 0,658065 & 0,658065 & 0,662903 & 0,580645 & 0,653226 & 0,658065 & 0,672581 \\
\hline 3 & 0,643548 & 0,653226 & 0,0643548 & 0,648387 & 0,769355 & 0,633871 & 0,648387 & 0,633871 \\
\hline 4 & 0,527419 & 0,619355 & 0,619355 & 0,580645 & 0,629032 & 0,619355 & 0,624194 & 0,614516 \\
\hline 5 & 0.658065 & 0.769355 & 0.662903 & 0.827419 & 0,672581 & 0,658065 & 0.682258 & 0,658065 \\
\hline
\end{tabular}

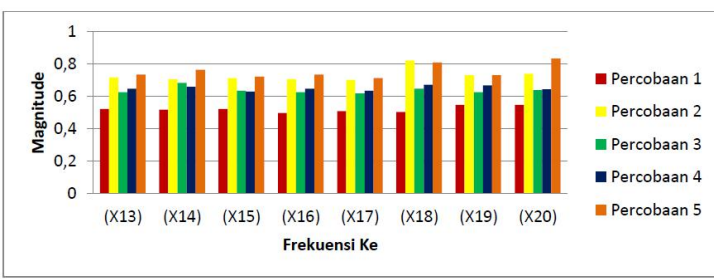

Gambar 12. Grafik respon sensor terhadap sampel halitosis akut

Dari hasil uji yang disajikan pada tabel 7 dan gambar 12, dari kelima percobaan diatas didapatkan hasil yang berbeda. Jarak magnitude yang di dapatkan dari 0 sampai 1 . Grafik respon sensor tertinggi terdapat pada percobaan ke-2 yang diikuti percobaan ke-5 pada counter ke-18 dan ke-20 yang nilai magnitude spektrumnya melewati angka 0,8 .

\section{Pengujian Sistem Keseluruhan}

Pengujian sistem secara keseluruhan dengan menggunakan metode LVQ. Input yang digunakan sebanyak 8 yang berasal dari keluaran FFT dan 4 output. Digunakan sebanyak 4 output karena kategori hasil yang diinginkan yaitu tidak halitosis, halitosis ringan, halitosis sedang dan halitosis akut.

\section{Uji Training Learning Vector Quantization}

Proses training yang dilakukan pada metode LVQ terhadap sampel tidak halitosis, halitosis ringan, halitosis sedang dan halitosis akut, dimana input data diambil dari nilai magnitude 32 counter dari hasil output FFT.

Delapan input untuk proses training, yaitu counter ke $13,14,15,16,17,18,19$, dan 20 yang merupakan pola unik yang telah didapat dari output FFT. Tabel 8 memperlihatkan data bobot awal training yang akan digunakan pada proses uji LVQ.

Tabel 8. Bobot awal training

\begin{tabular}{|c|c|c|c|c|c|c|c|c|c|}
\hline DATA & \multicolumn{8}{|c|}{ BOBOT AWAL TRAINING } & KELAS \\
\hline & $\mathrm{X} 1(13)$ & $\mathrm{x} 2(14)$ & $\mathrm{X} 3(15)$ & \begin{tabular}{|l|l|}
$\mathrm{X} 4(16)$ \\
\end{tabular} & \begin{tabular}{|l|}
$X 5(17)$ \\
\end{tabular} & $\mathrm{X} 6(18)$ & \begin{tabular}{|l|l|}
$x 7(19)$ \\
\end{tabular} & $\mathbf{X s}(20)$ & \\
\hline 1 & \begin{tabular}{|l|}
0,309677 \\
\end{tabular} & 0,304839 & 0,285484 & 0,217742 & 0,227419 & 0,275806 & 0,290323 & 0,227419 & 1 \\
\hline 2 & \begin{tabular}{|l|l|}
0,382258 \\
\end{tabular} & 0,41129 & 0,377419 & 0,425806 & 0,445161 & 0,459677 & 0,469355 & 0,464516 & 2 \\
\hline 3 & \begin{tabular}{|l|l|}
0,716129 \\
\end{tabular} & 0,706452 & 0,71129 & 0,706452 & 0,701613 & 0,822581 & \begin{tabular}{|l|l|}
0,730645 \\
\end{tabular} & 0,740323 & 3 \\
\hline 4 & 0.677419 & 0.658065 & 0.658065 & 0.662903 & 0,580645 & 0.653226 & 0,658065 & 0.672581 & 4 \\
\hline
\end{tabular}

Nilai bobot awal didapatkan dari hasil deviasi seluruh sampel dari 5 percobaan yang telah dilakukan sebelumnya. Pada proses training ini terlebih dahulu ditentukan nilai alpha sebesar 0,05 dengan penurunan tingkat pembelajaran sebesar 0,1*alpha dan maksimum epoch-nya sebesar 100 .

Proses training LVQ dilakukan menggunakan pemograman Matlab untuk mendapatkan nilai bobot. Pada proses training, target kelas ditentukan untuk dijadikan hasil identifikasi terhadap sampel yang akan diuji. Kelas ditentukan berdasarkan 4 inputan sampel yang diambil. Bobot hasil setelah training menggunakan Matlab dapat dilihat pada table 9 berikut.

Tabel 9. Bobot akhir hasil training pada matlab

\begin{tabular}{|c|c|c|c|}
\hline $\mathbf{W}(\mathbf{1})$ & $\mathbf{W}(\mathbf{2})$ & $\mathbf{W}(\mathbf{3})$ & $\mathbf{W}(\mathbf{4})$ \\
\hline 0,3916 & $-0,1441$ & 0,4810 & 1,0910 \\
\hline 0,4300 & 0,0207 & 0,4020 & 0,6561 \\
\hline 0,2373 & $-0,2407$ & 0,3942 & 0,7930 \\
\hline 0,2016 & 0,1207 & 0,4295 & 0,6743 \\
\hline 0,2376 & 0,2540 & 0,2411 & $-0,0210$ \\
\hline 0,4503 & 0,2991 & 1,1379 & 0,4379 \\
\hline 0,3518 & 0,3604 & 0,5654 & 0,6742 \\
\hline 0,2404 & 0,4470 & 0,7217 & 0,7732 \\
\hline
\end{tabular}

Bobot akhir training ini akan menjadi bobot identifikasi yang selanjutnya akan digunakan sebagai identifikasi hasil keputusan semua sampel uji pola data FFT yang telah didapatkan, apakah tidak halitosis, halitosis ringan, halitosis sedang dan halitosis akut. Berikut adalah hasil uji Bobot Akhir Hasil Training LVQ dengan input hasil FFT yang dapat dilihat pada tabel 10 .

Tabel 10. Bobot akhir hasil training LVQ

\begin{tabular}{|c|c|c|c|c|c|c|c|c|}
\hline DATA & \multicolumn{7}{|c|}{ BOBOT AKHIR } \\
\hline 1 & 0,3916 & 0,43 & 0,2373 & 0,2016 & 0,2376 & 0,4503 & 0,3518 & 0,2404 \\
\hline 2 & $-0,1441$ & 0,0207 & $-0,2407$ & 0,1207 & 0,254 & 0,2991 & 0,3604 & 0,447 \\
\hline 3 & 0,481 & 0,402 & 0,3942 & 0,4295 & 0,2411 & 1,1379 & 0,5654 & 0,7217 \\
\hline 4 & 1,091 & 0,6561 & 0,793 & 0,6743 & $-0,0201$ & 0,4379 & 0,6742 & 0,7732 \\
\hline
\end{tabular}

\section{Uji Identifikasi}

Proses identifikasi yang dilakukan hampir sama dengan proses training, proses ini dilakukan untuk 
mencari selisih terkecil atau jarak minimum antara vektor input dengan bobot akhir hasil training. Kelas ditentukan berdasarkan data input sampel mana yang diambil. Karena terdapat 4 sampel maka kelas yang digunakan juga 4, dimana masing-masing kelas mewakili ouput dari hasil identifikasi. Kelas $1=$ tidak halitosis, kelas $2=$ halitosis ringan, kelas $3=$ halitosis sedang dan kelas $4=$ halitosis akut.

\section{Tidak Halitosis}

Uji identifikasi sampel tidak halitosis dilakukan dengan 4 kali percobaan masing-masing 8 buah input spektrum dan 4 buah output proses identifikasi yaitu Y1 (tidak halitosis), Y2 (halitosis ringan), Y3 (halitosis sedang) dan Y4 (halitosis akut). Hasil uji sampel tidak halitosis ini dihasilkan suatu keputusan bahwa sampel teridentifikasi tidak halitosis $100 \%$. Karena dari ke-4 pengujian didapatkan jarak terpendeknya terletak pada Y1 yang mewakili kelas (tidak halitosis) terdapat sebanyak 4 kali atau semuanya terpenuhi, yakni pengujian ke-1 didapatkan $\mathrm{Y} 1=0.9973$, pengujian ke-2 Y1= 1.0116, pengujian ke-3 Y1=0,9937 dan pengujian ke-4 Y1=0,9732. Berikut adalah hasil identifikasi sampel tidak halitosis yang disajikan pada tabel 11 berikut.

Tabel 11. Identifikasi sampel tidak halitosis

\begin{tabular}{|c|c|c|c|c|c|c|}
\hline $\begin{array}{l}\text { No } \\
\text { Uji }\end{array}$ & $\begin{array}{l}\text { Jenis } \\
\text { Sampel }\end{array}$ & $\begin{array}{l}\text { Input } \\
\text { Ke- }\end{array}$ & $\begin{array}{ll}\text { Nilai } & \text { Input } \\
\text { FFT } & \\
\end{array}$ & $\begin{array}{l}\text { Output Proses } \\
\text { Identifikasi }\end{array}$ & \begin{tabular}{|l|} 
Kelas \\
Identifi \\
kasi
\end{tabular} & \begin{tabular}{|l|} 
Hasil \\
Identifikasi
\end{tabular} \\
\hline 1. & $\begin{array}{l}\text { Tidak } \\
\text { Halitosis }\end{array}$ & $\begin{array}{l}1 \\
2 \\
3 \\
4 \\
5 \\
6 \\
7 \\
18\end{array}$ & $\begin{array}{l}0,30483871 \\
0,319354839 \\
0,314516129 \\
0,324193548 \\
0,309677419 \\
0,150000000 \\
0,29516129 \\
0,280645161\end{array}$ & $\begin{array}{l}Y 1=0,9973 \\
Y 2=1,0195 \\
Y 3=1,1818 \\
Y 4=1,1628\end{array}$ & 1 & $\begin{array}{l}\text { Tidak } \\
\text { Halitosis }\end{array}$ \\
\hline 2. & $\begin{array}{l}\text { Tidak } \\
\text { Halitosis }\end{array}$ & $\begin{array}{l}1 \\
2 \\
3 \\
4 \\
5 \\
6 \\
7 \\
8\end{array}$ & \begin{tabular}{|l|}
0,45483871 \\
0,45000000 \\
0,464516129 \\
0,45000000 \\
0,464516129 \\
0,464516129 \\
0,474193548 \\
0,440322581 \\
\end{tabular} & \begin{tabular}{|l}
$\mathrm{Y} 1=\mathbf{1 , 0 1 1 6}$ \\
$\mathrm{Y} 2=1,0165$ \\
$\mathrm{Y} 3=1,0716$ \\
$\mathrm{Y} 4=1,0760$
\end{tabular} & 1 & \begin{tabular}{|l|} 
Tidak \\
Halitosis
\end{tabular} \\
\hline 3. & $\begin{array}{l}\text { Tidak } \\
\text { Halitosis }\end{array}$ & $\begin{array}{l}1 \\
2 \\
3 \\
4 \\
5 \\
6 \\
7 \\
8\end{array}$ & $\begin{array}{l}0,280645161 \\
0,198387097 \\
0,30483871 \\
0,280645161 \\
0,270967742 \\
0,256451613 \\
0,261290323 \\
0,246774194\end{array}$ & $\begin{array}{l}\mathrm{Y} 1=0,9937 \\
\mathrm{Y} 2=1,0228 \\
\mathrm{Y} 3=1,1864 \\
\mathrm{Y} 4=1,1784\end{array}$ & 1 & $\begin{array}{l}\text { Tidak } \\
\text { Halitosis }\end{array}$ \\
\hline
\end{tabular}

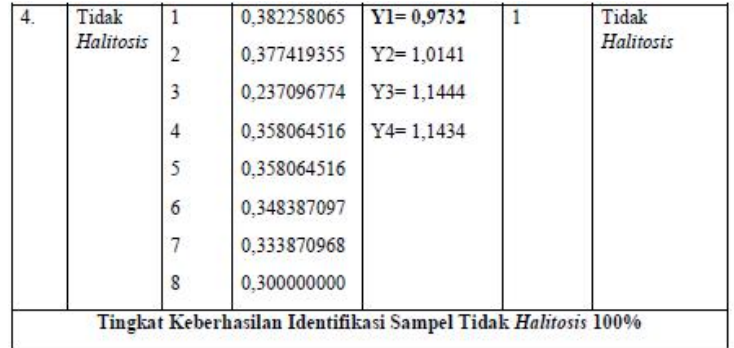

\section{Halitosis Ringan}

Uji identifikasi sampel halitosis dilakukan sama caranya dengan sampel tidak halitosis. Hasil uji menunjukkan bahwa tingkat keberhasilan identifikasi sampel halitosis ringan adalah sebesar $25 \%$. Hal ini dapat dilihat dari ouput hasil identifikasi dimana Y2-nya muncul dengan nilai terkecil satu kali $\mathrm{Y} 2=1.0362$ yang mewakili kelas halitosis ringan hanya teridentifikasi satu kali yaitu pada pengujian yang ke-4.

\section{Halitosis Sedang}

Hasil uji sampel halitosis sedang menunjukkan bahwa tingkat keberhasilan identifikasi sampel halitosis sedang adalah sebesar 50\%. Hal ini diperoleh karena terdapat dua kali nilai Y3-nya muncul dengan nilai paling kecil, yakni $\mathrm{Y} 3=1,0322$ pada pengujian ke-3 dan $\mathrm{Y} 3=1,0347$ pada pengujian ke-4.

\section{Halitosis Akut}

Uji identifikasi sampel halitosis akut dilakukan sama caranya dengan sampel halitosis ringan. Hasil uji menunjukkan bahwa tingkat keberhasilan identifikasi sampel halitosis akut adalah sebesar $50 \%$. Hal ini dapat dilihat dari ouput hasil identifikasi dimana Y4-nya muncul dua kali dengan nilai terkecil $\mathrm{Y} 4=1,0406$ pada pengujian ke-2 dan Y4=1,0329 pada pengujian ke-4 yang mewakili kelas halitosis akut.

\section{KESIMPULAN}

Kesimpulan

1. Hydrogen Sulfida (H2S) merupakan indikator yang dominan dari terjadinya halitosis.

2. Sensor TGS-2602 memiliki sensitivitas dan selektifitas yang baik pada kontaminasi udara terhadap kadar gas diluar ruang seperti Hidrogen Sulfida (H2S).

3. Tingkat keberhasilan sensor terhadap identifikasi sampel tidak halitosis 100\%, sampel halitosis ringan 25\%, sampel halitosis sedang 50\% dan sampel halitosis akut $50 \%$. 
Saran

1. Sebelum pengambilan data dilakukan, pastikan ruang sensor tertutup rapat agar data lebih akurat.

2. Untuk memberikan hasil yang optimal, sebaiknya menggunakan lebih dari satu sensor.

\section{DAFTAR PUSTAKA}

Alee, Ranjam. 2013. Reading Data From a Digital Multimeter Using Raspberry Pi. Turku University Of Applied Sciences.

Anonim. Tanpa tahun. Gas Sensor TGS 2602, http://www.figarosensor.com/. Diakses tanggal 19 Februari 2015

Anonim. Tanpa tahun. Gas Sensor TGS 2602, http://www.figarosensor.com/. Diakses tanggal 19 Februari 2015

Gunardi, Indrayadi, Yuniardini S Wimardhani. 2009. Oral Probiotik: Pendekatan Baru

Nasir, M, Syahroni, M, Pengujian Kualitas Sidik Jari Kotor Menggunakan Learning Vector Quantization (LVQ) Jurusan Teknik Elektro Politeknik Negri Lhokseumawe.

OhO, T., Yoshida, Y., Shimazaki, Y., Yamashita, Y., Koga, T. 2001. Characteristics of patients complaining of halitosis and the usefulness of gas chromatography for diagnosing halitosis. Fukuoka Japan Kyushu University. Vol. 91 No. 5 May 2001.

Putra, D.A. 2013. Identifikasi Penyakit Halitosis dengan Sensor Gas menggunakan Jaringan Syaraf Tiruan Metode Pembelajaran Backpropagation.Sistem Komputer Fakultas Teknologi Informasi Universitas Andalas.

Widagdo, Yanuaris, Suntya, Krisna. Volatile Sulfure Compounds sebagai penyebab halitosis. Fakultas Kedokteran Gigi Universitas Mahasaraswati Denpasar.

Tallamma, F, Efektifitas Ekstrak Daun Kemangi (Ocimim Basilicium L) Terhadap Penurunan Kadar Volatile Sulfure Compounds (VSCS) Fakultas Kedokteran Gigi Universitas Hasanuddin Makassar. 